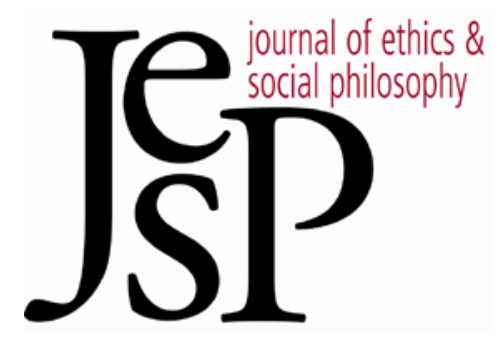

\title{
The Normative Significance of Conscience
}

\author{
By KyLE SWAn And KeVIn Vallier
}

JOURNAL OF ETHICS \& SOCIAL PHILOSOPHY

Vol. 6, No. 3 | SePtember 2012 URL: WWW.JESP.ORG COPYRIGHT (C) KYLE SWAN AND KEVIN VALLIER 2012 


\title{
The Normative Significance of Conscience
}

\author{
Kyle Swan and Kevin Vallier
}

\section{$\mathrm{M}$}

EMBERS OF LIBERAL SOCIETIES respect conscience. They generally consider it wrong to force another to do something she thinks is morally odious. John Rawls asserts, "the question of equal liberty of conscience is settled. It is one of the fixed points of our considered judgments of justice" (1971: 206). In this paper, we attempt to explain why liberty of conscience is a fixed point, or, why conscience has normative significance. Our answer, which draws on the resources of the contractualist tradition in moral philosophy, is not only of interest in its own right, but also clarifies a number of practical questions concerning the legal protection of conscience. We begin in section 1 by developing a definition of conscience and explaining what it means to violate conscience. In section 2 , we criticize three attempts to explain the normative significance of conscience, including Martha Nussbaum's recent defense. In section 3, we develop a contractualist explanation of the normative significance of conscience that we believe can remedy the defects in the accounts assessed in section 2 and ground a norm of respect for conscience. In section 4, we conclude.

\section{What Is Conscience?}

Conscience is a faculty of moral reasoning. When John asserts that, say, his conscience requires pacifism, he acknowledges pacifism as a deliverance of this moral faculty. It is often claimed that an intervention, such as conscripting John to fight in a war, violates his conscience. However, if conscience is a faculty of moral reasoning, this standard way of speaking is misleading since it is unclear how a faculty can be violated. We would do better to say that violating John's conscience means to force him to act contrary to his judgments. Therefore, we should rather say that John's freedom of action is restricted when he is forced to do something that contravenes some deliverance of his conscience. The claim that "conscripting John for military service violates his conscience" is simply shorthand for the idea that conscription would violate John because his faculty of moral reasoning delivered the judgment that it is wrong for him to kill people. Shorthands like this are useful and we may use them in the discussion that follows. When we do use them, however, keep in mind that violations of conscience are violations of a person, rather than a faculty or a judgment.

Many understand conscience as a faculty of perception, but we want to avoid the implication that conscience is a faculty that perceives an external moral reality. Such a view has figured prominently in the history of philosophy, and we will discuss it in section 2 , but here we propose a definition of conscience that is neutral between views that understand conscience as a basic perceptual faculty that directly or immediately receives information 
about moral reality and views that understand conscience subjectively, as a faculty of reasoning where moral judgments are mediated through other beliefs and attitudes of the agent. To define conscience as a basic perceptual faculty would be to endorse a substantive characterization against subjective interpretations in our definition and preclude an assessment of more recent understandings of conscience.

Conscience is not implicated in all moral judgments. Rather, it is the human faculty that delivers judgments that lie at the core of one's moral judgments. To understand the idea of a core moral judgment, consider a moral judgment that is clearly not a dictate of conscience. Brody judges that he should not go into the office this particular Sunday. His family has been complaining that he spends too much time working, so he feels guilty and concludes that he ought to stay home. This conclusion is a moral judgment, but were his boss to require that he come to the office on Sunday, we should not say that Brody's boss violated his conscience. Suppose, however, that John is a practicing Christian who believes that God has set apart Sundays for worship and rest. Then suppose John's boss forces him to come to the office on Sunday, causing him to violate this duty to God. Here, the requirement violates John's conscience by contravening a core moral judgment: his judgment that he has a duty to God not to work on Sundays. But what distinguishes the latter "core" judgment from the former more peripheral one? In our view, moral judgments are judgments about what moral reasons agents have. We shall understand some of these moral reasons in deontological terms as making categorical demands of individuals. Conscience is the faculty of moral judgment that generates categorical reasons for action grounded in a core of a network of moral reasons. Core moral reasons are moral reasons that have significant importance in an individual's practical deliberations and, consequently, order and structure the agent's entire network of moral reasons. ${ }^{1}$ They are reasons on which peripheral reasons rely in order to acquire their normative force. John may judge that he has reason to organize his workweek in such a way that all his responsibilities at work are met before Sunday. John's reason to do so is not "core" but depends on a core moral judgment that he has a duty to God not to work on Sundays. His reason not to work on Sundays orders and structures his reason to work longer hours during the week or not to procrastinate on projects.

Core moral reasons are often tied to deeply held principles and important personal life projects. These principles and projects often derive from what P. F. Strawson calls "individual ideals," those principles and evaluations that "govern choices and decisions which are of the greatest importance to men" (1974: 31). Individual ideals are descriptions of highly valued forms of life. Examples include the ideals of the major world religions. If

1 A significantly important judgment is one that actually figures into an actor's practical deliberations and network of reasons, not a judgment that an actor simply believes figures into her practical deliberations and network of reasons. 
Reba is a Muslim and has an individual ideal of obedience to Allah, then she will adopt a set of core principles and pursue a series of projects, such as fasting during Ramadan and avoiding pork and alcohol. These core-derived projects determine many of her other reasons, affecting whom she marries, where she lives and which restaurants she patronizes.

We may now say that conscience is a faculty that delivers core moral judgments, judgments that concern the reasons entailed by individual ideals. It is now easier to explain what a violation of conscience consists in. Recall that consciences themselves are not violated; rather, when we say that someone's conscience is violated, we just mean that a person has been forced to contravene the judgments of her conscience. Therefore, if Reba merely fails to live up to her core moral judgments or her individual ideal, she has not violated her conscience. For instance, suppose that Reba grows lax in her Islamic practice or starts to visit restaurants that are not certified Halal. Reba has not thereby violated her conscience. To violate Reba's conscience, someone must compel her to contravene her core moral judgments. Thus, we shall define a conscience violation as follows:

$A$ violates $B$ 's conscience iff:

(1) $A$ coercively interferes with $B$;

(2) $A$ 's coercive interference compels $B$ to contravene $B$ 's core moral duties.

The first condition employs the admittedly complex concepts of coercion and interference. To avoid well-known theoretical controversies, we shall simply define interference as an act that reduces the option set of another. Interference is coercive, we will say, when it reduces the option set by way of a perceived threat. Accordingly, a coercive interference need not be intentional, though it must be perceived to be such..$^{2}$ All that is required is an action that reduces someone's option set by way of some perceived intentional threat. ${ }^{3}$ The first condition holds that $A$ brings this about in $B$. The second condition requires that for $A$ to violate $B$ 's conscience, $A$ must compel $B$ to contravene $B$ 's core moral duties. $A$ reduces $B$ 's option set in such a way that $B$ will contravene her duty or, if she performs it, $A$ will introduce some other significant cost. For instance, suppose that John employs Reba and that jobs are scarce. If John threatens to fire Reba unless she converts from Islam to Christianity, then he compels her to violate a number of core duties or lose her job. John's interference thereby produces a significant loss in her wellbeing. ${ }^{4}$

2 There are controversies about whether interference and coercion must be intentional (Pettit 1997: 53 and Rhodes 2000: 68). We do not think their outcomes will make a difference to our thesis.

${ }^{3}$ Suppose that a naval vessel has a chapel that the captain removes in order to create space for more weaponry. While religious sailors no longer have a place to worship, the captain has not violated his sailors' consciences, as he did not remove the chapel by means of a perceived threat.

${ }_{4}$ Or, she might suffer the cost of having violated her principles. 
The second condition also employs the concept of a core moral duty. Suppose that Reba has a list of Muslim-friendly restaurants, but that the restaurants are ranked. Lower-ranked restaurants have a number of Halal options, but they are not Halal certified. That is, their menus contain some items that are forbidden to Muslims. If John threatens to fire Reba unless she joins colleagues for a working lunch at a lower-ranked restaurant, he has not violated her conscience. She could simply order the veggie plate. John's threat here reduces her option set and may reduce her well-being by some amount, but he does not compel her to contravene any moral duty. If such lunches are common practice in John's office, and if he in other ways cultivates an environment where Muslims do not feel welcome or part of the "team," he may be guilty of some kind of workplace discrimination, but not a violation of conscience. It is only if John's interference forces Reba to contravene one of her core moral duties, like the duty to avoid pork, that he violates her conscience.

Finally, the second condition connects the relevant moral duties to individual ideals, since these duties are rooted in her core moral reasons. To illustrate, consider a moral duty not rooted in one's individual ideal. Suppose that Reba's Islamic faith does not commit her concerning whether she is permitted to exploit a loophole in accounting procedures to improve the appearance of her company's balance sheet. Nonetheless, she regards herself as having a professional moral duty not to deviate from standard industry practices. If John threatens to fire Reba unless she utilizes the more creative accounting method, he has not thereby violated her conscience. This is because Reba's reason not to deviate from standard accounting practices is not a core moral reason rooted in her individual ideal. According to our analysis, it could be a core moral reason - individual ideals do not have to have religious moorings. Suppose Reba identifies with the stalwart heroes of corporate accountancy. If her associated ideal includes strict adherence to standard practices, then her professional duties would be sufficiently close to her core moral reasons that John's threat would count as a conscience violation.

\section{Three Accounts of the Significance of Conscience}

In this section, we will critically examine three accounts of the significance of conscience: (1) Martha Nussbaum's recent positive appraisal account, (2) the psychological distress account and (3) the externalist account. These are accounts of why people should not violate the consciences of others, or alternatively, why people should respect the consciences of others. We are guided in these critical comments by our discussion of what conscience is and how it is violated. Conscience is a faculty that delivers core moral judgments and is violated by some coercive interference with an agent that compels her to contravene one or more of her core moral duties. 


\subsection{Nussbaum's Positive Appraisal Account}

Martha Nussbaum has recently advanced a positive appraisal account of the normative significance of conscience. She argues, in short, that conscience should be respected because it is a faculty that searches for meaning. It is thereby worthy of positive appraisal by others. Nussbaum claims to follow Roger Williams in this by arguing that respect attaches to the faculty that searches for meaning rather than its conclusions. People need not respect the value endorsed by the faculty in order to respect conscience. Indeed, people should avoid conditioning their respect on a judgment that others are using the faculty wisely or competently. While we agree in identifying conscience as a faculty, Nussbaum understands the faculty somewhat differently, distinguishing it "in part by what it does - it reasons, searches, and experiences emotions of longing connected to that search - and in part by its subject matter - it deals with ultimate questions, questions of ultimate meaning" (2008: 169). Nussbaum stresses that moral persons must respect the faculty rather than its "goal" and that they must avoid "prejudging the question whether there is a meaning to be found ... From the respect we have for the person's conscience ... it follows that we ought to respect the space required by any activity that has the general shape of searching for the ultimate meaning of life" (24). Nussbaum aims to articulate an account that avoids judgments about what is intrinsically valuable, judgments about which people widely disagree and that ties respect to a faculty that practically every human being possesses, thus grounding an egalitarian form of respect. As she notes in her discussion of Roger Williams, "the faculty with which each person searches for the ultimate meaning of life is of intrinsic worth and value, and is worthy of respect whether the person is using it well or badly" (168-69). Thus, persons should respect the faculty regardless of its deliverances. ${ }^{5}$

Nussbaum contrasts her view with a principle of "mere toleration." She worries that mere toleration of diverse views is "too grudging and weak" to properly ground freedom of conscience (24). Toleration is insufficient because "everyone has inside something infinitely precious, something that demands respect from us all" (24). Moral persons should rather "revere ... the sincere quest for meaning." "This aspect of Nussbaum's account seems to rely upon something like Stephen Darwall's well-known distinction between recognition respect and appraisal respect. ${ }^{7}$ Nussbaum's argument implicates the latter as the proper basis for understanding the normative significance of conscience. We understand views like this as positive appraisal accounts.

\footnotetext{
5 Or, regardless of its deliverances within an appropriate range. Nussbaum claims that it is only appropriate to respect conscience that does not violate "the rights of others or comes up against some compelling state interest" (169).

${ }^{6}$ Emphasis added (52).

7 Darwall 1977. Brian Leiter (2010) has mapped Darwall's distinction onto Nussbaum's views.
} 
According to Darwall's distinction, people are worthy of appraisal respect when they demonstrate some sort of merit according to a relevant standard. It is a form of esteem. People are due respect in virtue of their actions, achievements, virtues and the like. Recognition respect, in contrast, is typically thought to be due all human beings regardless of any distinguishing merit. It is an acknowledgment - in one's attitude or disposition toward others - of their equal status and worth, which requires that they be given appropriate consideration in deliberations about what to do. One might interpret Nussbaum as grounding respect for conscience in the fact that people loyal to their consciences are worthy of appraisal respect just because they endeavor in a search for meaning. In fact, the deliverances of conscience and actions taken in accord with it often seem worthy of positive appraisal, but there are grounds for positive appraisal even when it is reasonable to think that another's judgment has gone awry. Brian Leiter puts the point this way:

Often when we admire someone's loyalty or devotion to a cause or a person, we admire their willingness to remain committed to it, notwithstanding countervailing evidence. ... In those cases we think the loyalty or devotion has some value either to the person or the cause so valued, or that it exemplifies a trait of character or habit of mind that is otherwise valuable (955).

It is common that someone will admire others who are loyal to principles she thinks are wrong, who support bad causes in an honest way or who follow even silly principles to their own detriment. Suppose John is an enthusiastic meat eater. Taking his cue from the great culinary traditions of the world, he reserves some space for other animals both in his conception of what it means to eat well and, indeed, on his plate. At the same time John endorses the steadfast devotion of conscientious vegetarians to principles that he tends to think are wrongheaded or misapplied. Moreover, he considers laudable the principles that call for reflection on eating ethically and minimizing unreasonable suffering in non-human animals. Or recall Reba's conscientious commitment to Islam's prohibitions of certain foods. One could admire her loyalty to God when she refuses to eat at a restaurant that is not Halal certified, even if one denies that God requires any such thing or, for that matter, even exists.

We have three concerns about Nussbaum's account. First, grounding respect for conscience in the search for an individual ideal is insufficient to ground respect for conscience in the full range of cases commonly thought appropriate. It appears that, for Nussbaum, only those who are still searching for meaning can have their consciences violated, but not those who have firm convictions about what their consciences require of them. The search for meaning often involves and terminates in the embrace of particular views, such as when someone settles on an individual ideal. In that event, it is the fact that someone has embraced an individual ideal that gives us reason to respect her conscience. Indeed, it is not altogether clear that interfering with someone's search for meaning violates conscience at all (though such inter- 
ference is immoral in most cases). For if Reba has no individual ideal, it is hard to see how John can force her to violate her deeply held principles, undermine her core projects or contravene her core moral duties. By stipulation, she does not have any. Consequently, Nussbaum's account seems to tie the normative significance of conscience to an inappropriate anchor.

A second concern is that Nussbaum's account seems to involve the very judgments about intrinsic value that she wants to avoid. Why exactly is the search for ultimate meaning worthy of respect? For Nussbaum, this search is a capability: "Political respect is addressed, in the first instance, to a 'capability' of people, one that demands both development and exercise; it is not addressed, except derivatively, to the functions such a faculty performs" (2008: 169). In another passage concerning the intrinsic value of religious belief, she claims that the "liberty of religious belief, membership, and activity is among the central human capabilities" (2001: 179). According to Nussbaum, religious capabilities are related to the more general categories of capabilities of sense, imagination, thought and affiliation. She takes these capabilities, and a list of eight other central categories, to be intrinsically good for human beings to have: "the central capabilities are not just instrumental to further pursuits: they are held to have value in themselves, in making the life that includes them fully human" (2001: 74). Therefore, for Nussbaum, the reason that religious ways of life and the search for ultimate meaning are worthy of respect is because the faculties related to them are intrinsically good to have. When she identifies the search for ultimate meaning as a capability, as she does in the quotation above, she commits herself to the value judgment that having the capability to act according to conscience is intrinsically good precisely because it is a central human capability, a basic component of well-being and human flourishing. This judgment is subject to some reasonable disagreement; for instance, many religious traditions will deny that the capability to search for meaning as such is intrinsically valuable or a basic component of well-being. While the problem we raise here points only to an inconsistency in Nussbaum's account of the normative significance of conscience, it illustrates how appealing to a search for meaning to explain the normative significance of conscience indicates that such an explanation will, explicitly or implicitly, require appealing to some intrinsic good. Otherwise, it is unclear why a search for meaning per se is worthy of respect.

People often judge that others' sincere searches for meaning go seriously awry. Our third concern with Nussbaum's account is that people tend to believe that violations of conscience can be immoral even when others' consciences motivate them to perform actions or embrace principles that do not render them worthy of appraisal respect. Suppose that John strives to raise his children according to his conception of Christianity. Suppose that his neighbor, Brody, is as committed to atheism as John is to Christianity and as committed to raising his children to be atheists as John is to raising his children to be Christians. John embraces historical, biblical Christianity; he believes that Brody, by raising his children to accept atheism, puts the souls of 
these children at risk of damnation. But Brody identifies with the new movement of "militant" atheists. From his point of view, John's decision to raise his children in the Christian faith squashes the autonomy of these children and is a form of child abuse. Each acknowledges that the other is acting in accord with his conscience, yet neither acknowledges any reason to positively appraise the way the other raises his children. In many contexts they may have some reason to positively appraise the loyalty and devotion of someone to principles they deny, but not when they judge that those principles lead to significant harm. If appraisal respect is the only or main reason to not violate conscience, then it is hard to see why John and Brody should not do quite a lot that would count as violating conscience to save the other's children from such damaging influences. In this case, appraisal respect does not explain why they should not violate one another's consciences.

We conclude that Nussbaum's positive appraisal account cannot adequately ground respect for conscience. In section 3, we propose that reasons not to violate conscience are reasons to offer recognition respect to a person committed to her own individual ideal, since we think that respect for conscience (within an appropriate range) is due to all persons, not for their actions or good qualities but because they are persons. Moral persons extend recognition respect to all people, but not appraisal respect.

\subsection{The Psychological Distress Account}

When someone settles on an ideal or project, interferences that compel her to violate it will cause psychological distress (Jenkins 1955). Thus, conscience is normatively significant, it is sometimes said, because violating conscience causes stress and psychological harm, which is normatively significant. In Welsh v. U.S. (1970), the majority decision overturned Welsh's conviction for refusing to report for military duty on the grounds that conscientious objectors to war conscripted to fight would have "no rest or peace if they allowed themselves to become a part of an instrument of war."' Steven Smith identifies this as a "basically utilitarian response" (2005: 337). We should not subject others to stress and psychological harm if we can help it; if violating conscience causes significant psychological harm, then that is a reason not to violate conscience.

It is certainly true that potential psychological harm provides a reason not to violate conscience. But psychological distress does not provide the sorts of reasons to respect conscience that we think are typically required to

8 Welsh v. United States, 398 U.S. 333 (1970), p. 344. The most historically significant aspect of the case, however, is that it extended conscientious objector status to those outside of the traditional confines of "religious" objector associated with belief in a supreme being. Justice Black wrote for the majority, arguing that the idea of conscientious objection has a broad scope and that asking objectors to figure out whether they have an appropriately "religious" objection "places undue emphasis on the registrant's interpretation of his own beliefs." We briefly address the matter of religious versus secular conscience in section 3 . 
explain conscience's normative significance. Suppose that John is a heroin addict who has been arrested. The police force him to stop taking heroin while he is incarcerated. Certainly John will suffer extreme psychological distress by being deprived of his heroin, but John's psychological distress at this is not likely a reason to permit him to shoot up. If conscience derives its significance from the psychological distress caused by actions violating it, then those who defend this account may be committed to accommodating anyone who experiences severe psychological distress so as to permit her the means to relieve that distress or prevent the psychological harm in the first place. To borrow an example from Nussbaum, "nobody wants to give a draft exemption to someone who is intensely attached to his car, however sincere the attachment may be" (2008: 167). This is precisely right; psychological distress may provide reasons to respect conscience but these reasons can be too easily overridden in ways most people do not think claims of conscience usually should be. Thus psychological distress proves an inadequate explanation of the normative significance of conscience. Recall that we identify a conscience violation with forcing an individual to contravene her core moral duties, but forcing someone to violate a duty and causing someone psychological distress need not overlap. Psychological distress may arise in cases where no core moral duty is violated; similarly, though less often, forcing some individuals to violate their core moral judgments may not cause psychological distress. Someone with a stoic disposition, for example, will naturally resent being forced to contravene a core moral duty, even if she will not be emotionally exasperated about it. Nussbaum makes this point when she argues that subjectivist accounts of conscience, accounts that ascribe normative significance to conscience on the grounds that religious convictions, for instance, usually involve "very strongly felt commitments, commitments central to a person's life"; she notes here that there are cases of religious membership that are "habitual and not particularly emotional" but still have normative significance, and that there are cases of emotional attachment that include, say, one's local sports team, that are irrelevant to violations of conscience (167). Psychological distress is thus both over- and under-inclusive. While psychological distress resulting from violating a core moral duty may be of greater moral significance than psychological distress caused by something else, psychological distress by itself cannot provide a foundational explanation of the normative significance of conscience. 9

We do not wish to discard the psychological distress account too quickly, however. Even if psychological distress does not provide a foundational explanation of the normative significance of conscience, it arguably plays a constitutive role in some violations of conscience. For instance, the forced

9 The same considerations seem to undermine Chandran Kukathas' subjectivist account grounded in people's basic human "interest in living in accordance with the demands of conscience" (2007: 55). Lucas Swaine (2008: 69-72) raises some of these problems for Kukathas' account. 
contravention of some core moral judgment may simply neurologically entail great psychological distress in a given agent. In such cases, we suggest that the tie between the forced contravention of the duty and its psychological consequences would be tight enough to demonstrate that psychological distress forms part of our reasons not to impose upon the conscience of the agent in question.

\subsection{The Externalist Account}

Many in the history of philosophy have held that conscience is an infallible guide to moral truth. For example, Benjamin Whichcote's view is that "Conscience is God's vice-regent, the God dwelling within us" (2010/1753: Aphorism 1058). Bishop Butler believed that all are naturally endowed with a conscience, a faculty that "pronounces determinately some actions to be in themselves evil, wrong, unjust, [that] without being consulted, without being advised with, magisterially exerts itself" (1950/1726: Sermon II). He further writes: "Conscience ... carries its own authority with it, that it is our natural guide ... assigned us by the Author of our nature: it ... is our duty to walk that path, and follow this guide" (Sermon III). For views like this, the normative significance of conscience is that conscience gets it right. More recently, Steven Smith has argued that "the case for respecting conscience may turn to a significant extent on what we think 'morality' is" (2005: 339). He concludes that "the case for conscience seems to depend on metaethical objectivism on a commitment to the idea that morality is in some sense natural, or given, or objectively true" (357) and that one's conscience at least attempts to make contact with it. On one elaboration of this externalist view of the significance of conscience, to violate conscience is to deny individuals the right to act on the Truth; not merely the truth as they see it or the truth for them, but on the Truth Itself. While the fact of reasonable evaluative pluralism seems to indicate that conscience is not an infallible guide, we might still think that conscience reliably tracks morally right acts. Proponents of this view could then explain away the fact that consciences diverge on the grounds that consciences loosely track some values in a plural scheme or can be confused by false beliefs about relevant nonnormative facts. The normative significance of conscience would be that the exercise of conscience often leads to true beliefs about important matters. While individuals sometimes err, it is still appropriate to respect their consciences because they have a general tendency to discover the truth. An analogy might be drawn with John Stuart Mill's defense of free speech: Free speech should be protected by law because it helps people to learn the truth, reminds the public why it endorses certain truths and allows falsehoods to propagate in order to help expose false beliefs (1991/1859: 20ff). Conscience should be respected, it might be argued, because a norm of respect for conscience will deliver the same social benefits. When conscience is respected, it leads over a period of time to knowledge of the truth and living in accord with genuine values. 
Externalist accounts will not do, either. In our terminology, conscience deals with individual ideals, which need not overlap or concern themselves with moral truth (or Truth). We adopted such a definition because members of liberal societies do not only respect consciences that tend to get at the truth; their respect for conscience extends much further. When we respect conscience, what is objectively right is not the point. We have described a number of cases where recognition respect is clearly owed to people who may not only get things wrong, but also to people whose consciences direct them to do what many regard as horrifying and abominable and who may well be unreliable with respect to the truth. Suppose that too many late nights surfing the outer reaches of the Internet have produced in Brody an esoteric obsession with government conspiracy theories. He now believes that vaccination programs, rather than promoting public health, allow the government to implant tracking devices in people's bodies and know where they are at all times. For reasons of bodily integrity and privacy, Brody refuses to submit to the flu vaccination. He is not reliable with respect to the truth; in fact, due to his esoteric obsession and penchant for such theories, he may well reliably track the silly. However, modulo genuine concerns about public health, Brody may have a legitimate claim not to have his conscience violated by forcing him to be vaccinated. We should reach the same conclusion were Brody to refuse because he is a Christian who believes that the "vaccination conspiracy" is a plot to institute the New World Order and usher in the reign of the Antichrist, which he believes is prophesied in Ezekiel, Daniel and Revelation in the Bible. From Brody's perspective, he has a religious duty to resist being vaccinated. ${ }^{10}$

A defender of the externalist account might reply that conscience is worthy of respect because as a general human faculty it tends to track the truth, not because each individual conscience tends to track the truth. But it is not clear how this response provides any reason not to violate Brody's conscience. The reply may ground respect for most human beings, but it is hard to see how it could ground respect for all of them. Members of liberal societies widely acknowledge that conscience should be respected when one's conscience is wrong as well as when it is right. In fact, to only respect conscience in cases where people think it is correct is not really to respect conscience at all. To respect conscience in accord with the externalist account simply involves permitting people to act on the reasons most others think are good. But that is not what it means to respect conscience; a norm of respect for conscience requires refraining from coercively interfering with another's

${ }^{10}$ However, not just any objection to forms of treatment will be sufficient to ground a claim of conscience. Brody's conclusion that he has this moral duty should issue from some minimally credible forms of inference and not be based in obvious factual errors or basic mishaps in reasoning. This requirement is not a concession to externalist views. If Brody could readily acknowledge, perhaps with a bit of help, that he has reason to consent to the vaccination, then his initial objection was out of line with his own rational and evaluative commitments. 
freedom to act in accordance with her core moral duties even when people do not approve of the principles her conscience delivers. ${ }^{11} \mathrm{~A}$ defender of the externalist account may express puzzlement at all of this: If judgments of conscience may not even tend to track the truth and objective rightness is not in view, then what authority can they claim? Consider the example of conscripting John, a pacifist, to fight in a war. Members of liberal societies tend to defer, if they can help it, to the claims of conscientious objectors. But why should they care about John's individual ideal? Certainly, people recognize it as a good thing when someone complies with a moral duty, but it is somewhat less clear that anyone should think there is any good in scrupulous compliance with something that she denies is a moral duty. So, what significance does conscience hold? Why should anyone, including the state, defer to what other people's conscience delivers to them or even care at all when, essentially, these claims amount to an expression of a subjective individual ideal? We now turn to this challenge.

\section{A Contractualist Account of the Normative Significance of Con- science}

In this section we argue that contractualism helps answer the question: Why should we respect the consciences of others? 12 We will proceed in four parts. First, we will briefly explain how we understand contractualism..$^{13}$ Second, we will place conscience within the first-person point of view of contractualist moral theory. Third, we will sketch how the first-person point of view in contractualism comes together with the second-person point of view. Finally, we will argue that this dual structure in the theory entails that people's reasons to act in line with their own goals and values will commit them to respecting others' reasons to act on theirs. In brief, people have reason to respect the consciences of others because they have conclusive reason to reject a proposal that would violate their own consciences.

\subsection{Contractualism}

Contractualist moral theory holds that a moral norm is binding if those to whom it applies could be reasonably expected to endorse it. ${ }^{14}$ Its proponents regard this as the most general explanation and justification of the normative force of moral norms (Scanlon 1998: 4; Darwall 2006: 27). Contractualist

11 Thus to violate conscience is not merely to interfere with the faculty that produces these judgments. Activities that interfere with the faculty (torture, brainwashing) are not paradigmatic violations of conscience.

12 Or, "Why shouldn't we violate the consciences of others?"

13 While there are different contractualist views, the success of our argument does not turn on their differences.

14 Thomas Scanlon appeals to a standard of reasonable rejection in his formulation of contractualism (1998: 4). We discuss the view in terms of the reasonable endorsability standard. 
moral theorists fit within the deontological tradition of moral theory, which we take to hold that promoting value is not the only basic or foundational way to appropriately respond to value; rather, value should sometimes be respected (Gaus 2001). In particular, deontologists hold that persons should be respected and that the value of persons establishes reasons to treat them in certain ways.

Contractualism interprets responding to the value of persons as requiring that everyone gives what is sometimes called a public justification for our practices of exercising or maintaining normative authority over others. ${ }^{15}$ The need to provide adequate justification is obvious when Brody wants to convince Dorothy of some idea. It is needed simply as a practical matter, given Brody's aim. Contractualists argue that matters differ when Brody attempts to exercise authority over Dorothy. Contractualists maintain that in order to treat Dorothy as a free and equal person, Brody's interference must be justified to Dorothy with reasons that she is reasonably able to endorse. That is, if Brody wishes to respect Dorothy's moral freedom and equality, rather than simply oppress or browbeat her, Brody's interference must be justified in terms of reasons that connect up with Dorothy's own sense of what is right and valuable. Briefly, respect for persons requires that coercing others be justified to them in terms that they can reasonably be expected to endorse. We find the idea of the reasonable to be somewhat vexed, but understand what persons can reasonably be expected to endorse in terms of their rational commitments to principles, values, projects, beliefs and the like. Thus, making moral demands of others, interfering with them, coercing them, etc., is justified only if their values, principles and so on conclusively commit them to the legitimacy or authority of those demands, interference or coercion.

\subsection{The First-Person Standpoint in Contractualism}

We take contractualism to affirm two fundamental standpoints within social morality: a first-person moral standpoint and a second-person moral standpoint. Accordingly, in contractualist moral theory people not only reason from their own standpoints, but also from the standpoints of others (Darwall 2006: 3). Contractualism contains a fundamental dual commitment to reasons to act on one's own commitments and values and reasons to respect the same reasoning and action in others.

The first-person standpoint contains all of what we shall call first-person reasons, or the reasons to act that people recognize as implied by their own values, principles and plans. The sphere of first-person reasons covers all of the reasons people have to act on their individual ideals. In this way, at the heart of first-person reasons are those reasons derived from individual ideals.

15 Following Gaus (2011: 2-13), we take the ideal of public reason as more or less synonymous with contractualist moral theory, and thus do not limit the test of public justification to political theory. 
This is not to say that there are no other first-person reasons, but for people with even partial individual ideals, the reasons that derive immediately from these ideals are the core moral reasons discussed in section 1. Thus, people's reasons to act consistently with their consciences are at the heart of their first-person reasons (Childress 1979). Our conception of conscience can thereby be integrated into contractualist moral theory.

We use the term "integrated" with some care. One might argue that our conception of conscience fits contractualist moral theory too neatly, since, insofar as contractualism acknowledges the normative force of first-person reasons, it already acknowledges the normative force of reasons of conscience. According to this objection, the connection here seems almost definitional rather than explanatory. Perhaps the circle of explanation is too tight. However, contractualism makes room for the normative force of first-person reasons not merely to safeguard conscience but also because persons are taken to be fundamental sources of reasons. Reasons of conscience are recognized because they are some of the most significant reasons acknowledged by persons. But contractualism takes such reasons seriously not because they are reasons of conscience but rather because they are reasons deeply interwoven into a person's reasons for action, such that taking a person to be a source of reasons means according these reasons normative significance. Reasons of conscience can be integrated into contractualism; they are not included by definition.

\subsection{The Second-Person Standpoint in Contractualism}

Stephen Darwall defines the second-person standpoint as "the perspective you and I take up when we make and acknowledge claims on one another's conduct and will" (2006: 3). To demonstrate that moral norms are binding on others and to justify blaming others for violating moral norms, people must reason from the standpoint of others. Darwall argues that agents must take the second-person standpoint to hold others blameworthy for violating social morality. When John takes the second-person standpoint, he can recognize the reasons Reba takes herself to have. To appropriately blame her for violating a norm, John must find that she had a reason to obey that norm. Otherwise, it is hard to see how he could be justified in blaming Reba for violating it. After all, blaming someone is appropriate only when that person is responsible for some moral violation, i.e., when she could have chosen otherwise and knew better than to act as she did. For Darwall, therefore, if in taking the second-person standpoint John does not discover that Reba is committed to a norm, he cannot appropriately blame her. Instead, by blaming Reba, John disrespects Reba. In this way, contractualists can be said to hold that respect requires that moral norms be publicly justified to those upon whom they are imposed. If indeed persons are moral equals, in the sense that none has natural authority over others, then those who make moral demands of others face the burden of justifying the exercise of authority in di- 
recting their actions. To respect others, for Darwall and other contractualists, is to treat them as moral equals by offering them a justification for the demands we make of them. ${ }^{16}$

The second-person element in contractualist moral theory provides an account of second-person reasons, or reasons to engage in the practices characteristic of social morality. For instance, if Reba steals from John, and there is a justified moral norm prohibiting stealing, John has a second-person reason to blame Reba. He can legitimately direct her: "Don't take my possessions!" And Reba has a second-person reason to accede to the demand, to take John's perspective in this matter and respond appropriately. Secondperson reasons also circumscribe the actions that we have first-person reasons to take. Jürgen Habermas has characterized taking the perspective of others in terms of "decentering" (1999: 132), following Jean Piaget. When moral agents take the standpoint of others they do not cease to take their own perspective or acknowledge the force of their own reasons. Rather, they take the reasons of others to have normative authority in determining, in part, which actions they may take. Mature moral beings reason from both their own first-person standpoint and from the standpoint of others. Thus, they must weigh their first-person reasons to act against the second-person reasons they have with respect to the moral norms they believe are justified to all persons. In particular, they will often have second-personal reasons to permit others to act on their first-person reasons. In other words, there will be cases where they will have reason to give up acting on their first-person reasons to allow others to act on theirs.

Why should anyone take the standpoint of others if it requires limiting her own sphere of action? For some, it may seem irrational to give the reasons of others so much weight relative to their own. Several traditions in moral philosophy have struggled with this "Why be moral?" question. Some have tried to give a wholly instrumentalist case for morality, where one's first-person reasons lead by logical inference to embracing second-person reasons (Gauthier 1986). Others are skeptical of this project (Gaus 2011: 53ff). Some take the second-person standpoint to be a basic feature of morality, arguing that it cannot be understood in simpler terms. Any reasons we give to take the second-person standpoint will be "reasons of the wrong kind" (Darwall 2006: 66; Scanlon 1998: 160ff). But we do not need to take a position on this debate in our sketch of a contractualist account of the significance of conscience.

16 What if John finds that Reba believes she has no reason to obey an otherwise intuitively legitimate norm? Is she blameworthy if she disobeys it? In cases like this, correctly attributing a reason for acting to Reba and making an intuitively plausible moral judgment may come apart. To resolve this apparent disconnect, we should first further examine whether Reba is right to believe that she has no reason to obey the norm or whether she could, perhaps with a bit of help, readily acknowledge a reason to obey it in terms of her own rational and evaluative commitments. If not, then the intuitive idea that John and Reba can achieve authoritative moral relations with each other may simply turn out to be too optimistic. 


\subsection{Respect for Conscience}

If there are reasons to take the standpoint of others, then individuals will have cause to accord normative significance to the reasons of others. Accordingly, those who assert the normative significance of their first-person reasons must, on pain of inconsistency, respect the first-person reasons of others. Normal people capable of functioning in society decenter in the sense that they take the perspective of others in determining how they should act. If people have reason to decenter, this justifies the widespread understanding that, if we demand that others respect our authority to act in accord with our reasons, then we should extend the same authority to them. Presumably we have most reason to demand that others recognize our authority to act in accord with our core first-person reasons; that is, we have very strong reason to demand that others respect our own consciences. Thus, if conscience is indeed the faculty that delivers judgments about people's core first-person reasons, then in taking the second-person standpoint, we should recognize that we have similarly strong reason to respect conscience generally.

A commitment to reasoning from the standpoint of others, therefore, generally requires us to respect reasons of conscience more than any other sort. Since people's first-person reasons of conscience are often their most important reasons for acting, our commitment to reasoning from their standpoint should lead us to accord these reasons the authority to limit, in part, how we act. After all, we take our own reasons of conscience to be particularly strong. Refusing to appreciate the centrality and strength of others' first-personal reasons would thereby violate our commitment to taking their standpoint as normative. Consequently, taking the standpoint of others not only requires taking into account their reasons, but also taking into account the centrality and strength of those reasons for the person in question. In the event, we will have reasons to respect the consciences of others similar in strength to reasons we have to demand respect for our own. It will be particularly difficult to justify violating other people's consciences by forcing them to contravene their core moral duties. Claims of conscience are particularly powerful and weighty moral reasons for action; if we respect others, then we should do more to respect their reasons of conscience than any of their other reasons. Accordingly, justifying a violation of conscience will be quite difficult. ${ }^{17}$ We believe that this is true even for conscience violations that might promote the good of others. Perhaps we could make moral improvements by

17 A referee worries that this argument makes respect for conscience too demanding, especially in cases where appeals to conscience may stymie legitimate state purposes. However, in general, we acknowledge the difficulty of permissibly violating someone's conscience as a feature of our account, rather than a bug. That said, in some cases the barrier to governmental action can be overcome if citizens have an antecedent commitment to a political decision procedure the aim of which is to resolve conflicts between claims of conscience and pressing state purposes (see Gaus 1996: Part III). 
limiting people's opportunities to act on their consciences. For example, forbidding adherents of Santeria to practice ritual sacrifices may encourage more ethical treatment of animals. Banning the hijab in public may advance the well-being of some women raised in conservative Muslim families. Even in these cases, reasons to respect conscience remain strong - just as strong as the reasons that we take to apply in the case of our own conscientious commitments. Given that we have strong reasons of conscience that arguably block others from interfering with us even for our own good, we should acknowledge similarly strong reasons in others.

What explains the fact that reasons of conscience are among people's more important reasons for acting? In our view, it is because reasons of conscience are necessary components of an explanation of people's practical identities. Suppose that John's religiously based pacifism structures the constitution of John's identity. If so, then respecting John's reasons to act on his commitments is part and parcel of respecting who he is. In doing so, we acknowledge John as a being worthy of respect. Contrast this with John's more peripheral moral convictions. These do not help to explain John's practical identity and so should move us less, given that we would not expect the same deference from others with respect to our peripheral judgments. We can now see how contractualism explains how duties to respect conscience take precedence over many other sorts of reasons for action, including moral reasons. Contractualism is rooted in the recognition of persons as basic sources of reasons for action, and weighty sources at that. Consequently, contractualism prescribes reasons to respect conscience when conscience issues reasons that figure into a person's practical identity, her very conception of self.

In this way, contractualist moral theory explains the normative significance of conscience. People who are committed to reasoning from the standpoint of others are committed to respecting the consciences of others. Since we all want our consciences respected, we are all committed by the nature of second-person morality to respect the consciences of others. ${ }^{18}$ In one way, this insight is very simple - as simple as the Golden Rule. But the deep normative explanation of why conscience should be respected is illuminating. It is not enough to be satisfied with imprecise sketches of the normative significance of conscience, like those we discussed in section 2 , or to simply assume respect for conscience as a fixed point in morality. Instead, the conceptual tools of moral philosophy can be employed to develop a satisfying account of the normative weight of conscience. We recognize that the foregoing explanation of conscience is tied specifically to contractualist moral theory and that those who reject contractualism cannot endorse the account.

18 Perhaps a reasonable person might want her conscience corrected rather than respected if it is in error. Yet it is compatible with respect to offer considerations aimed at convincing another that her judgment is in error. It is not compatible with respect to coerce her compliance with values and ends that she has no reason to endorse. 
However, since in our view the explanation is compelling, there is reason to understand conscience in contractualist terms. At the very least, a contractualist account of the normative significance of conscience is a contender.

Another reason to accept our account is that it explains what seems correct about the accounts of conscience discussed in section 2. Nussbaum's insistence that conscience involves a search for meaning is similar to claiming that conscience often involves a search for an individual ideal. If so, then we can also accommodate this aspect of Nussbaum's account. Since people ascribe enormous value to their individual ideals, presumably the search for such ideals is worthy of respect as well. There is also no reason to deny that appraisal respect can provide additional reasons to respect conscience in cases where positive appraisal is merited, even if this is not an ultimate explanation of the normative significance of conscience.

Similarly, there is no reason to deprive psychological distress of its normative significance, as we suggest above. On the contrary, contractualism offers an explanation of why it matters to the extent that it does. First, moral agents have reason not to cause others distress simply because there is often no public justification for doing so. Given that such distress is a great harm to those who suffer it, they have no conclusive reason to endorse the behavior that causes it and, consequently, no one usually has justified authority to impose it. Second, psychological distress is often tightly correlated with individuals being barred from acting on the reasons that they recognize as having force. Thus, individuals who avoid imposing psychological distress on others remain in the vicinity of respecting the consciences of others.

Unfortunately, there is not much to say for the externalist account. A contractualist account of respect for conscience, by relying only on first- and second-personal reasons, provides what we might loosely call an internalist account of the normative significance of conscience. It therefore does not explain respect for conscience in terms of truth tracking. However, the externalist account does account for one aspect of why claims of conscience are significant. Most of us do not hold to our individual ideals willy-nilly. Instead, we hold to them because we think they are best. Conscience should be respected even when it does not reliably track the truth, but we can recognize that our consciences often reach out to an external world of value such that, if there is such a world, we would have strong first-person reason to grasp it.

In defending respect for conscience, we have primarily discussed the meaning and significance of conscientious judgments of individuals. We have refrained from taking up more complex issues related to the actual practice of negotiating situations where a proposed action or rule threatens to violate their consciences. A more complete account would address questions concerning what protections of conscience are legitimate or desirable: Should society defer to all claims of conscience or only some? Which ones? To what lengths must society go to respect claims of conscience? This is where the philosophical analysis of reasons to respect conscience pays off. There are countless issues about which citizens of states are conscientiously divided but 
which demand some resolution. In fact, in many cases some resolution must play out since even doing nothing will determine whether someone's conscience is violated. Political institutions will either extend accommodations for diverse consciences or not. Here we can only provide a rough approximation of some of the practical implications of a contractualist account of respect for conscience.

First, some have worried about what they see as a "progressive cheapening of conscience" in U.S. constitutional law (Smith 2005: 325). Marie Failinger recounts that freedom of conscience "began as an argument that government must ensure a free response by the individual called distinctively by the Divine within" but more recently "has come to mean very little beyond the notion of personal existential decision-making" (2000: 94). Our account allows us to avoid both of these unwelcome options. An individual ideal describes any of a large number of highly valued forms of life that influence one's moral duties and reasons for action. Not all claims of conscience are derived from a person's religious identification or beliefs. Accordingly, we suspect that nothing about the nature and significance of conscience justifies affording more protection or respect to religious assertions of conscience than to nonreligious, or secular, ones. ${ }^{19}$ At the same time, individual ideals are most closely connected to one's core moral duties and reasons, rather than any ethical or practical (or self-serving) decision one may reach in some context. In contexts where the state must make a determination about whether to accommodate a citizen's claim of conscience, our account appropriately highlights the importance of ascertaining the claimant's sincerity, though doing so may prove difficult.

Second, not all claims of conscience warrant respect or protection, all things considered. For example, Reba may believe that imposing her sectarian views on others is one of her core moral duties. On one level, it is understandable that Reba prefers to live according to this component of her individual ideal, but when this requires others to forego theirs, her imposition seems much less reasonable. In imposing her views on others, Reba fails to take their standpoint while expecting them to respect her conscientious commitments. As such, the claims she makes on others are not authoritative from their points of view. They can legitimately direct her to mind her own business and leave them alone. Reba has a second-person reason to accede to this demand. In effect, her first-person reason to live according to her own ideal conflicts with her first-person reason to impose her ideal upon others. The conflict occurs because Reba's first-person reason to live according to her own ideal coupled with her reason to take the standpoint of others implies the second-person reason to leave others to live according to their own ideals. Other people's individual ideals can override or undercut some of Re-

19 A country's legal history might justify treating religious and secular conscience differently, but nothing distinguishes them in terms of their normative significance. 
ba's reasons for action. According to this argument, claims of conscience that fail the contractualist test of public justification do not merit respect.

\section{Conclusion}

Claims of conscience merit respect because claimants take themselves to have the authority to demand similar respect from others. Anyone who has experienced the pull of her conscientious commitments would regard it as impermissible were others to violate them. Individuals are committed to respecting claims of conscience because they have second-person reasons to permit others to act upon their core, first-personal moral reasons. Standard explanations of the normative significance of conscience fail because they neglect this dual structure of moral reasons. Only a contractualist account extends the normative force we accord to our own first-person reasons for action to the first-person reasons of others. By emphasizing the standpoint of others, contractualism grounds our reasons to respect the consciences of others in the reasons we have to act in accord with our own consciences. Our account thereby explains why we have reason to restrict our sphere of action on behalf of others.

Liberal democratic societies have functioned so well because they implicitly recognize the challenge of balancing the force of first- and secondpersonal claims. They tend to have a place for both individual liberty and an impartially justified social morality. Achieving such a balance is the central challenge for any liberal society and respect for conscience is the most significant manifestation of this challenge. For this reason, a compelling account of the normative significance of conscience explains why members of liberal societies are right to value their common morality as they do.

Kyle Swan

National University of Singapore

Department of Philosophy

phisk@nus.edu.sg

Kevin Vallier

Bowling Green State University

Department of Philosophy

kevinvallier@gmail.com 


\section{References}

Butler, Joseph (1950/1726) Five Sermons Preached at the Rolls Chapel and a Dissertation upon the Nature of Virtue, Indianapolis: Bobbs-Merrill.

Childress, James (1979) “Appeals to Conscience," Ethics 89: 315-35.

Darwall, Stephen (2006) The Second-Person Standpoint: Morality, Respect, and Accountability, New York: Harvard University Press.

(1977) “Two Kinds of Respect," Ethics 88: 36-49.

Failinger, Marie (2000) "Wondering After Babel: Power, Freedom and Ideology," in Rex J. Ahdar, ed., Law and Religion, Burlington, Vt.: Ashgate, pp. 81-110.

Gaus, Gerald (2011) The Order of Public Reason, New York: Cambridge University Press.

(2001) "What Is Deontology? Part One: Orthodox Views," Journal of Value Inquiry 35: 27-42.

(1996) Justificatory Liberalism: An Essay on Epistemology and Political Theory, New York: Oxford University Press.

Gauthier, David (1986) Morals by Agreement, New York: Oxford University Press.

Habermas, Jurgen (1999) Moral Consciousness and Communicative Action, Cambridge: MIT Press.

Jenkins, Iredell (1955) “The Significance of Conscience," Ethics 65: 261-70.

Kukathas, Chandran (2007) The Liberal Archipelago, New York: Oxford University Press.

Leiter, Brian (2010) "Foundations of Religious Liberty: Toleration or Respect?" San Diego Law Review 47: 935-59.

Mill, John Stuart (1991/1859) John Stuart Mill on Liberty and Other Essays, John Gray, ed., New York: Oxford University Press.

Nussbaum, Martha (2008) Liberty of Conscience, New York: Basic Books. (2001) Women and Human Development: The Capabilities Approach, Cambridge: Cambridge University Press.

Pettit, Philip (1997) Republicanism, Oxford: Oxford University Press.

Rawls, John (1971) A Theory of Justice, New York: Oxford University Press.

Rhodes, Michael (2000) Coercion, Amsterdam: Rodopi.

Scanlon, Thomas (1998) What We Owe to Each Other, Cambridge, Mass.: Harvard University Press.

Smith, Steven D. (2005) "The Tenuous Case for Conscience," Roger Williams University Law Review 10: 337-58.

Strawson, P. F. (1974) Freedom and Resentment and Other Essays, New York: Routledge.

Swaine, Lucas (2008) The Liberal Conscience: Politics and Principle in a World of Religious Pluralism, New York: Columbia University Press.

Whichcote, Benjamin (2010/1753) Moral and Religious Aphorisms, Samuel Salter, ed., Whitefish, Mont.: Kessinger Publishing. 